Société d'histoire de la révolution de 1848 et des

révolutions du XIXe siècle

15 | 1997

1818. Nouveaux regards

\title{
Du patrimoine musical. Le concours de chants nationaux de 1848
}

\section{Sophie-Anne Leterrier}

\section{OpenEdition \\ Journals}

Electronic version

URL: http://journals.openedition.org/rh19/121

DOI: $10.4000 /$ rh 19.121

ISSN: $1777-5329$

\section{Publisher}

La Société de 1848

\section{Printed version}

Date of publication: 1 December 1997

ISSN: 1265-1354

\section{Electronic reference}

Sophie-Anne Leterrier, "Du patrimoine musical. Le concours de chants nationaux de 1848 », Revue d'histoire du XIXe siècle [Online], 15| 1997, Online since 10 September 2008, connection on 02 May 2019. URL : http://journals.openedition.org/rh19/121 ; DOI : 10.4000/rh19.121

This text was automatically generated on 2 May 2019.

Tous droits réservés 


\title{
Du patrimoine musical. Le concours de chants nationaux de 1848
}

\author{
Sophie-Anne Leterrier
}

\section{ABSTRACTS \\ No abstract available by now \\ Pas de résumé disponible actuellement}

INDEX

Mots-clés: 1848, Musique 